\title{
Religious interfaith work in Canada and South Africa with particular focus on the drafting of a South African Charter of Religious Rights and Freedoms
}

\author{
Author: \\ lain T. Benson ${ }^{1,2,3}$ \\ Affiliations: \\ ${ }^{1}$ Extraordinary Professor \\ of Law, Department of \\ Constitutional Law and \\ Philosophy of Law, Faculty of \\ Law, University of the Free \\ State, South Africa \\ ${ }^{2}$ Barrister \& Solicitor/Senior \\ Research Fellow, Chester \\ Ronning Centre for the Study \\ of Religion and Public Life, \\ University of Alberta, Canada \\ ${ }^{3}$ Research Associate, The \\ South African Institute for \\ Advanced Constitutional, \\ Public, Human Rights and \\ International Law (SAIFAC), \\ Johannesburg, South Africa

\section{Correspondence to:} \\ Iain T. Benson \\ Email: \\ iainbenson2@gmail.com \\ Postal address: \\ Ferme Loudas, Quartie \\ Serres, 65270 St. Pé de \\ Bigorre, France \\ Dates: \\ Received: 17 Aug. 2012 \\ Accepted: 27 Apr. 2013 \\ Published: 26 July 2013 \\ How to cite this article: \\ Benson, I.T., 2013, 'Religious \\ interfaith work in Canada \\ and South Africa with \\ particular focus on the \\ drafting of a South African \\ Charter of Religious \\ Rights and Freedoms', \\ HTS Teologiese Studies/ \\ Theological Studies 69(1), \\ Art. \#1319, 13 pages. \\ http://dx.doi.org/10.4102/ \\ hts.v69i1.1319

\section{Copyright:} \\ C 2013. The Authors. \\ Licensee: AOSIS \\ OpenJournals. This work \\ is licensed under the \\ Creative Commons \\ Attribution License. \\ Read online:

Constitutional protections for religious freedom (and related freedoms of conscience, belief and association and equality), once interpreted by courts and tribunals, apply in a precedential manner to future cases. They have an influence well beyond the particular community to which they first applied. For this reason, religious communities have increasingly banded together and sought to intervene or even, on occasion, to initiate legal actions asserting or defending their rights. This article reviews some of the principles around the freedom of religion as understood in South Africa and Canada to show how courts have understood the freedom of religion in its social context. In addition, interfaith cooperation is discussed with particular reference to the recent process which led to the formation of a Charter of Religious Rights and Freedoms pursuant to Section 234 of the South African Constitution (which is attached to the article). This section, a unique provision in any constitution, allows for the creation of additional Charters to give greater specificity to the general language of the Constitution itself. As such, it is an encouragement to civil society to determine what it thinks are the important provisions that should be spelled out to give guidance to politicians and the judiciary. Awide variety of religious groups participated in the creation of the Charter. The Charter does not claim to be, nor could it be, exhaustive of such concerns but demonstrates that religions can cooperate across a host of issues in education, health care, employment and other issues. The next stage - passage into law, is still in the future but the first important hurdle has been crossed with the signing of the Charter in October of 2010. The Charter might be a template for other countries though changes would be necessary to deal with local issues.

\section{Introduction}

The creation, under Section 234 of the Constitution of the Republic of South Africa, 1996 of a South African Charter of Religious Rights and Freedoms, is a development of major world importance. It will be, once passed into law, the first Charter created under this section. Its signing, at a public ceremony at the University of Johannesburg on October 21, 2010, in Johannesburg, concluded the first phase of civil society discussions, meetings, drafting and redrafting. ${ }^{1}$ Next it moves to the political phase for further discussions and it is hoped, eventual passage into law.

In the course of the preparation of the Charter, significant consultations with every major religious group (and many that would be considered minor) occurred and comments were assiduously considered by the Continuity Committee and the draft amended many times in response to these comments. The Continuity Committee was made up of some eight persons - one of whom is the writer of this article. The author has been involved in this process since near the beginning, and this article sets out some of the background to this work which remains, in some ways, a work in progress. Beyond the utility of the process to date (which has been most useful already in establishing links and discussion between widely diverse groups), should the Charter become a legal document, it will be the first such Charter created in South Africa and, because of the unique provision in the South African Constitution, likely the first of its kind anywhere. It will be possible, perhaps, to emulate it through laws in other countries but that is beyond the scope of this article.

The Charter's significance time alone will tell, but in view of the number of groups consulted, the time spent considering the language of the text and the number of areas covered, it has no equals in South African constitutional history.

\footnotetext{
1.The public signing ceremony occurred on Thursday, 21 October 2010 in the Main Board Room of the University of Johannesburg The event was attended by over a hundred delegates representing all the major religions of South Africa and several of the key Non-governmental organisations (NGOs) including the Section 185 (1) (of the Constitution of the Republic of South Africa, 1996) Commission for the Promotion and Protection of the Rights of Culture, Religious and Linguistic Communities. The event was covered by major radio and television. Various media interviews were conducted and the signing was mentioned on Radio 702 and the main evening television news on the South African Broadcasting Commission (SABC). Five people spoke at the ceremony: Constitutional Court Deputy Chief Justice Dikgang Moseneke (who spoke on the legal history of the idea of religious liberty), Professor Marinus Wiechers (former Vice-Chancellor, University of South Africa, who spoke on the importance of religious liberty), Dr Nokuzola Ndende (Continuation Committee Member, who spoke on African Customary Religions), Professor lain Benson (Canada and the University of the Free State, Continuation Committee Member, who gave an International Perspective) and Professor Rassie Malherbe (University of Johannesburg and Continuation Committee Member, who gave an overview of the Charter itself). A Council of Religious Rights and Freedoms was established by vote of the signatories present pursuant to section 185 (1) (c) and work in relation to that is ongoing.
} 


\section{What exactly is the proposed South African Charter of Religious Rights and Freedoms?}

Before reviewing the actual document and its specific rationale, it is useful to discuss some framework issues in relation to it. In particular, it is useful to put the Charter in context by discussing what courts have said about the nature and importance of religion generally.

\section{Religion is recognised as being important to societies and courts have recognised this}

Religions are very significant to cultures and the courts, and at least in this country this has been recognised.

Consider this statement from a South African Constitutional Court decision of a decade ago in its well known decision dealing with the question of corporal punishment for children in schools. Interestingly this decision (but not the passage referred to here) which deals with religious faith and culture, was referred to in a recent Supreme Court of Canada decision touching on religious rights. Here is what the South African court said in Christian Education South Africa $v$ Minister of Education:

For many believers, their relationship with God or creation is central to all their activities. It concerns their capacity to relate in an intensely meaningful fashion to their sense of themselves, their community and their universe. For millions in all walks of life, religion provides support and nurture and a framework for individual and social stability and growth. Religious belief has the capacity to awake concepts of self-worth and human dignity which form the cornerstone of human rights. It affects the believer's view of society and founds the distinction between right and wrong. (Christian Education South Africa v Minister of Education 20004 SA 757 (CC):para. 36; Currie \& De Waal 2005:336-357; Farlam 2003:ch. 41; Bruker v Marcovitz 2007 S S.C.R. 607; Boonstra \& Benson 2008)

Note in this passage that it is not a particular religion that is singled out here. The importance of religion 'for millions in all walks of life' is not limited to any particular religion and it will be noted that the protection of the freedom of religion in the Bill of Rights is not limited to any particular religion. In fact, the provision that protects 'religion' also protects the rights of 'belief' and of 'culture' and this, too, is not unusual.

Section 9(3) of the Constitution expressly prohibits unfair discrimination on a wide list of grounds. It reads:

The state may not unfairly discriminate directly or indirectly against anyone on one or more grounds, including race, gender, sex, pregnancy, marital status, ethnic or social origin, colour, sexual orientation, age, disability, religion, conscience, belief, culture, language and birth.

In a Canadian context, one of the sections that guarantees the right of religious freedom guarantees it equally with 'conscience' and section 2(a) of the Canadian Charter of Rights and Freedoms (Part II of the Constitution Act 1982) reads 'conscience and religion'.
Nowhere can a passage be found in a Canadian Supreme Court decision, or any other with which the author is familiar, that says the sort of thing referred to above from the Christian Education decision in South Africa. Canadian judges, and those in other countries, are much less confident about the important cultural role of religion or, alternatively, do not speak in such encouraging terms about it.

\section{What is wrong with simply leaving the development of principles to the courts on a case-by-case basis?}

\section{The limitations of litigation as a means of developing sound social policy and building civic society}

Litigation is not ideal for airing all the relevant issues in relation to important matters. There are various reasons for this.

Firstly, in any particular piece of litigation there is a 'hit and miss' aspect to what parties are before the court as litigants either as parties or as interveners. The latter, often having the greatest expertise in an area, also typically have a limited role in terms of taking the court record as it is found and having shorter time for argument and reduced written argument lengths et cetera.

Secondly, litigation is not the best strategy for a society to use as a method for nation building or the creation of communities of respect. The nature of the litigation means that not all aspects that should be dealt with are dealt with, often for political reasons. Thus, there was very little before the court in the same-sex marriage litigation in Canada dealing with the effects of single-sex parenting on children. The Attorney General of Canada lawyers had been instructed not to say or imply anything negative at all about 'same-sex parenting' and that political direction obviously affected what materials were before the Courts. ${ }^{2}$ By way of comparison, when the matter was actually debated and analysed in France (at least up until 2013 when unexamined political considerations again kicked in) that country decided to reject 'same-sex marriage'. This shows that, sometimes to a considerable degree, political or ideological concerns can lead to restraints on what sorts of information will be put before the court and, as the French situation showed up until the unilateral changes in 2013, such studies (psychological, anthropological and so on) can have a determinative outcome at least for a certain period of time. (National Assembly [France] 2006). ${ }^{3}$

Thirdly, there is the question of cost and who can afford to appear before the courts. Many of those in a position to make important arguments can simply not afford to be there. Coalition for Marriage and the Family in the Canadian challenges (launched in three jurisdictions) to the common-law recognition of marriage as heteros in three jurisdictions) to the common-law recognition of charriage as heterosexua and was told this by one of the counsel for the Federal Attorney General in one f

That Report in both full French and partial English versions may be consulted at http://www.preservemarriage.ca/docs/France_Report_on_the_Family_Edited.pdf 
Quite apart from these particular limitations to litigation, there is the wider problem that if power to determine all aspects of social policy shifts to the courts there is a temptation that with difficult matters (such as abortion or same-sex marriage) politicians try to avoid what to them is politically dangerous ground by shunting such determinations to activist courts rather than exercising political leadership to make determinations in the more suitable forum of legislative chambers. This was seen very clearly in the Marriage Reference in Canada where Justice Committee hearings on a proposed piece of legislation were simply cancelled once the government decided to state a Marriage Reference to the Supreme Court of Canada doing an 'endrun' both around the normal appeal process of cases in the courts and their own Justice Committee hearings. It was not democracy's finest hour in Canada when that occurred. But there is an even larger problem than this: by encouraging the courts to be primary formers of public policy in complicated areas without proper political and civil society inputs there is a reduced scope for negotiated compromises.

\section{As Canadian philosopher Charles Taylor (2001) has noted:}

Judicial decisions are usually winner-take-all; either you win or you lose. In particular judicial decisions about rights tend to be conceived as all-or-nothing matters. The penchant to settle things judicially, further polarized by rival special-interest campaigns, effectively cuts down the possibilities of compromise. (p. 116)

\section{Why interfaith religious cooperation?}

Some might ask why 'interfaith' religious cooperation should exist. Here again, the short answer is that the Constitution (in common with most countries) does not focus on 'the Christian religion' but on 'religion' and what happens to one religion in terms of an interpretation of the law will have an influence and impact on other religions. So it is necessary for those concerned about the rule of the law to recognise that all religions ought to be concerned how other religions are treated by politics and the law. In terms of formal cooperation, however, it seems to me that Canada has just naturally developed greater interfaith participation in relation to court challenges given its slightly longer constitutional history and court challenges program that existed for several years (the Canadian Constitution was re-patriated from the UK in 1982).

Canada as a matter of fact has had a history of 'interfaith' coalitions making successful attempts at intervention in some of the major court cases of the day where religious rights and freedoms are at issue.

Interfaith coalitions intervened first, with regard to the status of the unborn in a case dealing with abortion (Borowski $v$ Canada (Attorney General), [1989] 1 S.C.R. 342, late 1980s). Then, a few years later, in relation to statutory conjugal language in statutes dealing with 'sexual orientation' in the early to mid-1990s, (Egan and Nesbit $v$ Canada, [1995] 2 S.C.R. 513, 1995 SCC 49, 1994) similarly, as just mentioned, with respect to same-sex marriage itself (Barbeau v British Columbia
(A.G.) 2003 BCCA 406, Halpern v Canada, [2003] O.J. No. 2268 and the Marriage Reference re Same-Sex Marriage [2004] 3 S.C.R. 698, 2004 SCC 79, 2002-2006) all had interfaith interventions.

Interfaith, and sometimes expressly Christian groups (such as the Evangelical Fellowship of Canada or the Canadian Conference of Catholic Bishops), have also made frequent representations to House and Senate Committees on a wide variety of constitutional and social justice issues over the years.

The expressly interfaith (as opposed to simply Christian) coalitions that emerged in the 1990s in Canada were in part responsive to the fact that the concerns about the cases were shared across religious divides (such as the 'sanctity of life' with regard to the abortion issue). In addition, Canada, like South Africa, understands itself to be multicultural and pluralistic thereby lending a particular 'fit' to any application before the court that claims to speak about multicultural and inter-religious cooperation. ${ }^{4}$

In the same-sex marriage litigation in Canada, and cases leading up to it, various groups including the Evangelical Fellowship of Canada (representing some 30 or so Protestant churches), joined together with the Canadian Conference of Catholic Bishops to form a coalition to argue that pressure on the 'traditional' definitions of marriage would eventually put pressure on the religions themselves.

This concern, first expressed in the Canadian Supreme Court decision in Egan and Nesbit, (1995) 124 DLR (4th) 609, over the inclusion of same-sex couples into the definition of 'spouse' in the federal Old Age Security Act (1952), though dismissed as spurious by counsel for the claimant couple (and interveners on their side of the case), was subsequently proven to have been relevant. It was not much more than eight years later that the challenges to the common-law recognition of marriage as only between men and women arose in three Canadian provinces - British Columbia, Ontario and Quebec.

Again, an 'interfaith coalition for Marriage and the Family' responded, retained counsel and went into court arguing that attempts to force a national definition (the Federal Constitutional power dealing with the capacity to marry) of 'marriage' could put pressure to change their own understandings about the nature of marriage.

Whether interfaith or simply Christian, these coalitions failed to maintain a heterosexual-only recognition of marriage in both countries. Still, their expressed concerns about pressure being brought to bear on religious groups and individuals if the law changed, was heard and due to the involvement of religious groups arguing that their perspective be respected, decisions of the highest courts in both countries made express mention of religious protections. With respect to

4.Section 27 of the Canadian Charter of Rights and Freedoms requires the Courts to int 27 of the Canisan Charter of to interpret the provisions of the Constitution so as to enance Canada's 'multicultural ' rights of 'language' and 'cultural life' and the importance of 'culture', 'religious' and 'linguistic' communities. The Preamble to the Constitution of South Africa speaks of a country '... united in diversity.' 
this, the following decisions are relevant: the decision of the Supreme Court of Canada in Reference re Same-Sex Marriage 20043 S.C.R. 710 (Can) (the Marriage Reference) and the Constitutional Court of South Africa in Minister of Home Affairs $\mathcal{E}$ Another $v$ Fourie $\mathcal{E}$ (Doctors for Life International $\mathcal{E}$ Others, amici curiae); Lesbian and Gay Equality Project $\mathcal{E}$ Others $\checkmark$ Minister of Home Affairs 2006 1 SA 524 (CC) (Fourie).

\section{Interfaith coalitions and religious concerns about same-sex marriage}

The issue of marriage has been, if not the central focus of conservative religious groups in Canada concerning public policy, at least a major focus of these groups for well over a decade. In South Africa religious or religiously motivated groups similarly sought and obtained intervener standing in the Fourie-litigation and made representations before the Law Reform Commission.

Same-sex marriage, like the issue of abortion, has often sparked the formation of religious groups appearing as interveners before the courts in various countries. In many Canadian cases, a wide variety of religious and 'interfaith' interveners appeared and made arguments about the place and importance of religion in Canadian society. These arguments attempted to explain why issues such as the status of the unborn or same-sex marriage concerned religious groups. For example, as discussed above, in litigations involving same-sex marriage, ${ }^{6}$ the 'Interfaith Coalition on Marriage', composed of the national associations of Hindus, Sikhs, Muslims, Evangelical Protestants and Catholics, applied for and received intervener status in the three provinces where these cases were originally launched. ${ }^{7}$

On July 16, 2003, pursuant to Section 53 of the Supreme Court Act (RSC ch. S 26 § 531985 [Can]) the Parliament submitted three questions to the Supreme Court of Canada concerning the constitutionality of a proposed Civil Marriage Act (Reference re Same-Sex Marriage 20043 S.C.R. 698 [Can]). The third question, dealing expressly with the issue of religion, asked the following: 'Does the Freedom of Religion guaranteed by Section 2(a) of the Charter protect religious officials from being compelled to perform same-sex marriages contrary

5.The following section draws upon Benson (2007:141ff.)

6.These cases were launched close together in three provinces, British Columbia, Ontario, and Quebec. EGALE Canada Inc v Canada 2003225 DLR 472 (Can). Halpern v Canada 200365 OR3d 161 (Can); Hendricks v Canada 2004238 DLR 577 (Can). The cases went to the appeal level in all provinces before the appeals were abandoned prior to the Supreme Court of Canada level. The launching of the were abandoned prior to the Supreme Court of Canada level. The launching of the caucus much less the House of Commons) caught many by surprise and, in effect, conceded the main issues in the appeals and was a controversial 'end run' of the usual appeals process.

7.Affidavits on behalf of the 'Interfaith Coalition' in the 'same-sex marriage' litigations, for example, were filed on behalf of Judaism (Rabbi and political theorist David Novak), Roman Catholicism (Professor Ernest Caparros, professor of Canon law at the University of Ottawa and Professor Daniel Cere, Catholic political theorist at McGill University), Islam (Abdulla Idris Ali, past President of the Islamic Society at McGill University), Islam (Abdulla Idris Ali, past President of the Islamic Society of North America), and Evangelical Protestantism (Professor Craig Gay at Regen College). In each case, the teachings of the religious perspective with reference to the nature and place of marriage, the need for respect for the other groups and citizens irrespective of their sexual orientations, and concerns about where a reconfigured constitutional norm would place the religious groups themselves,
were the focus of the affidavits. At the Appeal Court levels, various 'reformed' were the focus of the affidavits. At the Appeal Court levels, various 'reformed
religious groups appeared in an effort to counter the traditional religious voices. to their religious beliefs?' (p. 721). The Supreme Court's decision in Reference re Same-Sex Marriage addressed these constitutionality concerns and demonstrated the Court's view on how religion coincides with sexual orientation rights in Canada. The decision by the Court was unanimous. The Justices' submitted only one set of reasons for their holding, and no individual Justice was credited as the author of the judgement (p. 705). The decision ignored the argument that 'marriage' exists prior to the state and to law, and does not depend upon (and never had in Canada) a 'legal definition'. The court quoted the leading English common-law case of Hyde v Hyde (1866 1 LRP \& D 130 [UK]) and, in particular a passage referring to a Christian basis for marriage in justifying its position:

What, then, is the nature of this institution as understood in Christendom? Its incidents may vary in different countries, but what are its essential elements and invariable features? If it be of common acceptance and existence, it must needs (however varied in different countries in its minor incidents) have some pervading identity and universal basis. I conceive that marriage, as understood in Christendom, may for this purpose be defined as the voluntary union for life of one man and one woman, to the exclusion of all others. (Reference re Same-Sex Marriage 20043 S.C.R. 710 (Can) - quoting Hyde v Hyde 18661 LRP \& D 133 [UK])

Of this passage the Supreme Court opined that:

The reference to 'Christendom' is telling. Hyde spoke to a society of shared social values where marriage and religion were thought to be inseparable. This is no longer the case. Canada is a pluralistic society. Marriage, from the perspective of the state, is a civil institution. (p. 710)

The Court held that the first question ('Is the proposed Act within the Exclusive Legislative Authority of the Parliament of Canada?' [pp. 708, 717-718]), was relevant to Section 2 of the proposed Act, which stated, 'nothing in this Act affects the freedom of officials or religious groups to refuse to perform marriages that are not in accordance with their religious beliefs' (p. 716).

The Court ruled that this provision was superfluous because the question of the solemnization of marriages, Section 92(12) of the Constitution Act 1867, gave the exclusive powers over the 'solemnization of marriages' to the provinces (as opposed to the capacity to marry - a federal issue), meaning that anything governing religious officials with regard to the performance of marriages must be governed provincially, and was ultra vires the Federal Parliament (716). The Court commented on the Act's stated purpose and its preamble as follows:

The preamble to the Proposed Act is also instructive. The Act's stated purpose is to ensure that civil marriage as a legal institution is consistent with the Charter: WHEREAS, in order to reflect values of tolerance, respect and equality consistent with the Canadian Charter of Rights and Freedoms, access to marriage for civil purposes should be extended to couples of the same sex; AND WHEREAS everyone has the freedom of conscience and religion under the Canadian Charter of Rights and Freedoms and officials of religious groups are free to refuse to perform marriages that are not in accordance with their religious beliefs ... (Reference re Same-Sex Marriage 20043 SCR 710 (Can):717-718) 
The Court rejected the arguments made by certain religious groups stating that the recognition of same-sex marriages would discriminate against them (pp. 717-718). The Court, in explaining its position, stated:

The mere recognition of the equality rights of one group cannot, in itself, constitute a violation of the rights of another. The promotion of Charter rights and values enriches our society as a whole and the furtherance of those rights cannot undermine the very principles the Charter was meant to foster. (p. 719)

In answer to concerns that civil access to 'same-sex marriage' would create a 'collision of rights' in the culture, the Court said:

The protection of freedom of religion afforded by [\$] 2(a) of the Charter is broad and jealously guarded in our Charter jurisprudence. We note that should impermissible conflicts occur, the provision at issue will by definition fail the justification test under [\$] 1 of the Charter and will be of no force or effect under [ $\S] 52$ of the Constitution Act, 1982. In this case the conflict will cease to exist. (Reference re Same-Sex Marriage 2004 S S.C.R. 710 [Can]:721)

On the third question, 'does the freedom of religion guaranteed by Section 2(a) of the Charter protect religious officials from being compelled to perform same-sex marriages contrary to their religious beliefs?' (p. 721), the Court pointed out that the compulsion which the question envisages, is by the state (p. 721). It also stated that such compulsion for officials or for 'sacred places' would violate the guarantee of freedom of religion under § 2(a) (pp. 722-723). Most significantly, the Court held this guarantee to be 'broad enough to protect religious officials from being compelled by the state to perform civil or religious same-sex marriages that are contrary to their religious beliefs' (p. 723). ${ }^{8}$

Though these comments were strictly obiter on matters relating to provincial jurisdiction and not before the Court in the case, the Court's statements, particularly with respect to the use of 'sacred places' (Reference re Same-Sex Marriage 20043 S.C.R. 710 [Can]:722) gave some measure of comfort to religious people though it left open various questions. For example, would 'sacred places' be construed widely as befits a liberal and broad reading of 'religion' or narrowly as befits a limiting provision? Contrary to the Court's statement a choice between approaches is itself a sort of 'rank-ordering' that does not make conflicts 'disappear'. The increased amount of litigation concerning religion that immediately followed suggests that the line between religious communities and the 'new constitutional norm' of same-sex inclusive marriage will be at the forefront of future debates and litigation. ${ }^{9}$ It also

8.Emphasis added. See also lacobucci (2003:137). The argument here is that 'reconciling' has advantages to 'balancing' as an analytical and practical tool in certain types of cases. The article reviews where reconciliation might be the best approach to what could, at first blush, appear to be a clash or conflict of rights. Of course the judgement left unanalysed an equally practical question: whether this protection for 'religious officials' would apply to the accommodation of civic officials say, Marriage Commissioners operating under state licenses that base thei objections on the constitutional grounds of 'conscience and religion'. That matter is academic opinion is divided on how they should be resolved. 9.See, for example, Smith v Knights of Columbus 2005 BCHRT 544. Here a lesbian couple sought to use a hall run by a Catholic organisation as a venue in which to hold their marriage celebration. Before the Human Rights Tribunal of British Columbia, the right of the religious group to restrict the use of its property with activities consistent with the core beliefs of the group was upheld. Despite this, however, the group was held to be liable for how it had dealt with the same-sex couple in the process of renting and then cancelling the contract. See also Boonstra and Benson (2006) (commenting on the situation regarding the scope of religious dissent to same-sex marriage as to both 'sacred places' as well as to personal objections). suggests that seeking a modus vivendi between alternative and irreconcilable positions might be more important than vesting just one viewpoint (same-sex marriage) as a new dominant position. Accomplishing this will require greater principled nuance than has traditionally been viewed in the 'same-sex rights advancement' debates.

The Justice Committee of the Federal Government conducted hearings on the proposed Government legislation (Bill C-38) in the spring and early summer of 2004 but these were cancelled as soon as the Marriage Reference was launched That the process, fully underway would be cancelled effectively circumventing the democratic voices in preference to judicial ones was greeted with surprise and astonishment by many of the members of this Committee which had by then held many hearings and planned many more. ${ }^{10}$ The new Civil Marriage Law that followed the Supreme Court decision and subsequent hearings before legislative committees, included amendments made as a result of suggestions by various representations, made to the House and Senate Committees. These amendments attempted to provide protection to the religious groups that dissented from the new Constitutional norm.

These amendments were passed, in part, to end the steady series of lawsuits filed against individuals, churches and groups, as well as to recognise the threats to religious groups that were evidenced in public statements. Some of these had expressly threatened religious communities or individuals on the grounds that they posed a threat to the new Constitutional (same-sex marriage inclusive) order. Certain activists went so far as to publicly state their intention to file lawsuits against religious charities if they did not begin to recognise samesex marriage, a result predicted by religious groups in their argument against same-sex marriage recognition (Robinson 2002-2003; Hutchinson 2005:A1).

Once the state determines that same-sex marriage is a constitutional right, religious beliefs upholding 'traditional' marriage will come increasingly into conflict with the new constitutional norm until such time as greater principles of public sphere sharing are developed. In order for this to occur, claims by same-sex activists to public sphere dominance, like all claims to dominance by one viewpoint on legally contestable matters, need to be identified and rejected. The status of a 'tolerated discriminator' looked - to many of these groups and individuals - like pretty thin ice (to use a particularly apt metaphor in a Canadian context) and that is an ice upon which many religious groups and organisations continue to feel themselves standing. The next section will address specific examples to illustrate some of the tensions that are emerging.

\section{Tolerance of difference: Conflicting rights}

An example of how disputes between differing views of marriage just do not 'disappear' with a balancing of rights approach (as the Supreme Court of Canada implicitly

10.The process and details on these hearings may be found at: http://www. religioustolerance.org/hom_marb5.htm 
suggested) may be seen in a case before the Human Rights Tribunal in British Columbia. Here a lesbian couple approached a Catholic organisation, the Knights of Columbus, to rent their hall for a marital celebration (Smith $v$ Knights of Columbus 2005 BCHRT 544). The right of the religious group to restrict the use of its property with activities consistent with the core beliefs of the group was upheld. Despite this, however, the group was held to be liable for how it had dealt with the same-sex couple in the process of renting and then cancelling the contract (p. 544).

Commenting on the situation regarding the scope of religious dissent to same-sex marriage (both as to 'sacred places' as well as to personal objections) the authors of a comment upon this decision observed:

The law in this area is a patchwork that needs clarification both on the federal and provincial level. It would be a good development if provincial legislatures, in particular, would fully analyze the impact of same-sex marriage on religious groups and legislate appropriate protection. Unless and until that happens, courts and tribunals will have to use the limited tools at their disposal to conduct this balancing. The results, like the outcome in this case, may be very confusing and insufficiently attentive to the real nature of a civil society in which people of differing beliefs have to co-exist in a real world of civilized disagreement on matters about which people may hold strong opinions and have the right to disagree. ${ }^{11}$ (Boonstra \& Benson 2006)

This sort of experience in Canada shows the importance of full, frank and open discussion socially about the consequences of same-sex marital inclusion or even the extent and reasons for same-sex beneficial inclusion (as distinct from marriage) as well as sufficient time, perhaps, to rethink how to deal with the interests of all citizens. ${ }^{12}$

Justice Albie Sachs, formerly of the Constitutional Court of South Africa, made the following thoughtful comment regarding the search for equality:

Equality should not be confused with uniformity; in fact, uniformity can be the enemy of equality. Equality means equal concern and respect across difference. It does not presuppose the elimination or suppression of difference. Respect for human rights requires the affirmation of self, not the denial of self. Equality therefore does not imply a levelling or homogenisation of behaviour but an acknowledgment and acceptance of difference. At the very least, it affirms that difference should not be the basis for exclusion, marginalisation, stigma and punishment. At best, it celebrates the vitality that difference brings to any society. (National Coalition for Gay and Lesbian Equality v Minister of Justice 199812 BCLR 1517:1574-1575)

Of course, one has to be careful in taking this approach that an unrealistic standard of human interaction is not adopted, lest 'hurt feelings' be elevated to a constitutionally-protected

11.Regarding the notion of 'society' or "civil society' Charles Taylor reminds us that society is prior to the state (law and politics): ' ... society is not constituted by the state but limits it' (Taylor 1995:287).

12.An extensive body of court decisions, Parliamentary speeches, and many academic articles concerning same-sex marriage, particularly from a Canadian perspective, may be found at the website of the Institute for the Study of Marriage, Law and Culture - http.//www.marriageinstitute.ca. From the other side of the argument on same-sex marriage, the leading source of web-based articles and information is the site of one of Canada's most sophisticated same-sex activist organisations Equality for Gays and Lesbians Everywhere (EGALE) - http://www.egale.ca. category, thereby watering down to an unacceptable degree the rigour of our conceptions of equality and dignity. ${ }^{13}$

As referred to above many religious bodies and interfaith groups have intervened in important cases touching on religious liberty over the past decade and a half in Canada. They have seen first-hand in situations such as the eradication of denominational education rights in Newfoundland and Quebec (Constitution Act 1867 \& 93A), that, in their view religious communities and individual believers are often not being accorded the respect they deserve and to which they are entitled (MacDougall 2006:353-354). ${ }^{14}$ In Canada, many religious believers and groups speak openly about feeling excluded and threatened by developments they see around them (Lafferty 2007:307-312). The breadth and depth of this concern is not something that any citizen should take lightly given the important role that religious beliefs play in society.

In South Africa, many religious believers were also concerned where changes to the legal understanding of marriage would take their own communities. Thus, in Fourie, religious groups sought and obtained, status as amicus curiae based on an affidavit by Cardinal Wilfred Napier, of the Roman Catholic Church.

In Christian Education, as we saw above, the majority of the Court was quite willing to comment on the importance of religious beliefs to South African society; we see the same openness in other more recent decisions of the same Court (Christian Education South Africa v Minister of Education 2000 4 SA 757 (CC):para. 36; Currie \& De Waal 2005:336-357; Farlam 2003:ch. 41; Bruker v Marcovitz 2007 SCC 54; Boonstra \& Benson 2008).

In Fourie, the majority of the Court found religious beliefs and their associations to be socially important in these terms:

Religious bodies play a large and important part in public life, through schools, hospitals and poverty relief programmes. They command ethical behaviour from their members and bear witness to the exercise of power by state and private agencies; they promote music, art and theatre; they provide halls for community activities, and conduct a great variety of social activities for their members and the general public. They are part of the fabric of public life, and constitute active elements of the diverse and pluralistic nation contemplated by the Constitution. Religion is not just a question of belief or doctrine. It is part of a people's temper and culture, and for many believers a significant part of their way of life. Religious organisations constitute important sectors of national life and accordingly have a right to express themselves to government and the courts on the great issues of the day. They are active participants in public affairs fully entitled to have their say with regard to the way law is made and applied. (Minister of Home Affairs $\mathcal{E}$ Another $v$ Fourie $\mathcal{E}$ Doctors for Life International \& Other; Lesbian and Gay Equality Project $\mathcal{E}$ Others $v$ Minister of Home Affairs 20061 SA 524 [CC]: paras. 90-93 \& 98)

13.The following decision of the Supreme Court of Canada has been subjected to just this criticism: Law v Canada (Minister of Employment and Immigration) 19991 S.C.R. 497 (Can) and Granovsky $v$ Canada 2000 SCJ No. 28. For a review discussing S.C.R. 497 (Can) and Granovsky v Canada 2000
both decisions see Benson and Miller (2000).

14.In favour of accommodating the right of officials not to perform same-sex marriages on the basis that tolerance allows for disagreement, see Lafferty (2007:307-312). 
Important to note here is the fact that the Court finds religion not simply to be an 'individual' matter but something important for the community and the whole society. ${ }^{15}$ The Court continued, however, with this observation setting out a limitation on the public use of religious argumentation:

It is one thing for the Court to acknowledge the important role that religion plays in our public life. It is quite another to use religious doctrine as a source for interpreting the Constitution. It would be out of order to employ the religious sentiments of some as a guide to the constitutional rights of others ... Whether or not the Biblical texts support his beliefs would certainly not be a question which this Court could entertain. From a constitutional point of view, what matters is for the Court to ensure that he be protected in his right to regard his marriage as sacramental, to belong to a religious community that celebrates its marriages according to its own doctrinal tenets, and to be free to express his views in an appropriate manner both in public and in Court. Further than that the Court could not be expected to go. (Minister of Home Affairs \& Another v Fourie E Doctors for Life International \& Other; Lesbian and Gay Equality Project $\mathcal{E}$ Others $v$ Minister of Home Affairs 20061 SA 524 (CC):paras. 92, 93 \& 98)

What the court wishes to see is coexistence within difference. If the experience in Canada is anything to go on, however, it is reasonable to suggest that such coexistence is going to require a considerable amount of litigation in order for the genuinely 'open' nature of the public sphere to be ensured. In the process of such litigation, a Charter of the sort that has now been signed in South Africa could be of considerable guidance to the courts and legislatures in terms of the key principles to be applied, though whether a genuinely open form of pluralism can be realised and maintained remains an open question.

Litigation in Canada over the past years has shown that for matters such as public school curricula, letters to the press, employment contracts and the nature of religious organisations themselves, it could be said that eternal litigation, rather than vigilance, is the price to be paid for liberty. This brings me to more particular questions about the creation of the South African Charter of Religious Rights and Freedoms.

\section{Why a charter in addition to the enumerated rights? \\ Two forms of civil society response to legislatures and courts - South African and Canadian}

The role that religions could play in relation to the ongoing formation of the South African constitution was understood early on by Justice Albie Sachs (1990) when he wrote:

Ideally in South Africa, all religious organizations and persons concerned with the study of religion would get together and draft a charter of religious rights and responsibilities.... it would be up to the participants themselves to define what they consider to be their fundamental rights. (pp. 46-47)

15.I have written about the tension between the right of religion and belief to be viewed 'individualistically' rather than in its (preferred) dimension - associationally both aspects should be kept in view. See Benson (2008:297, 297-312).
Section 234 of the Constitution of South Africa stipulates as follows: 'In order to deepen the culture of democracy established by this Constitution, Parliament may adopt Charters of Rights consistent with the provisions of the Constitution.'

The Constitution of the Republic of South Africa, 1996, was based in part on the Canadian Charter of Rights and Freedoms. The Canadian Charter contains no provision similar to Section 234 of the South African Constitution. The Canadian Charter provided a method of democratic response to judicial decisions by way of an override provision (Section 33) which allows laws to be continued in force for a limited time despite a judicial declaration of constitutional invalidity. ${ }^{16}$ Such a declaration is time-limited making it, so the theory goes, an election issue upon which a Government using such a declaration could fall. Given the political realities of South Africa, with the dominance of one party, such a provision would not work in principle or in practice as it could effectively suspend the Constitution without the likelihood of the ballot box providing accountability.

Section 234, on the other hand, gives South Africans a means to offer guidance to both politics and the courts though, since it has not been used until now, it is not certain what the political process will do to the work with which civil society (in terms of the major religions) has already been involved.

In principle, however, Section 234 gives those who come up with such charters, emerging from civil society, the chance to specify in greater detail what they think matters and the location of Section 234 in the Constitution suggests that legislation passed under this provision will be accorded a kind of 'super statutory' or constitutional status by virtue of that inclusion.

So what has happened in South Africa to date in terms of the South African Charter of Religious Rights and Freedoms?

\section{History of the South African Charter of Religious Rights and Freedoms}

The first formal substantive step towards the formation of the South African Charter of Religious Rights and Freedoms was when a group of legal and theological academics called a meeting in Stellenbosch in October 2007 at which a variety of groups (primarily Christian at the beginning though this 
changed over time) met to discuss the background to such a document and whether it would be advisable to develop such a document. The author spoke about the Canadian experience of 'interfaith cooperation' and how such cooperation is essential in constitutional democracies formed around notions of pluralism and multiculturalism. ${ }^{17}$

One conclusion of that meeting was that representation had to be extended further afield to invite all the major religions (including African customary religions) to attend to comment upon a basic draft that was to be prepared prior to that meeting and that particular care should be taken to invite all religions to the table.

The draft was prepared by a small working group and a further meeting called for February 14, 2008. Prior to that meeting an invitation was sent out to every major religion in South Africa inviting participation and stressing that the draft was completely open for discussion and was not in any way 'set in stone'.

The rationale document attached to the invitation which went out over the signature of theologian Dr Pieter Coertzen from Stellenbosch (but largely drafted by law Professor Rassie Malherbe from the University of Johannesburg) stated as follows:

Motivation for a Charter of Religious Rights for South Africa:

1. Section 234 of the Constitution of the Republic of South Africa, 1996, provides that 'in order to deepen the culture of democracy established by the Constitution, Parliament may adopt Charters of Rights consistent with the provisions of the Constitution', which charters will then, have the force of law. The Constitution envisages, in other words, that the rights in the Constitution may be further extended, supplemented and given content by way of such charters.

2. The room which Section 234 creates for a charter of religious rights provides religious institutions with a golden opportunity to take the initiative in a matter that is crucially important to every religious person and institution. In an open, free and democratic society it cannot be left to the state alone to determine the content of our rights. Structures such as religious institutions should make a contribution in areas in which they have a direct interest and of which they have intimate knowledge. If religious institutions succeed in submitting to the state a consensus proposal regarding a charter of religious rights, the state will hardly be able to ignore it. Thus, religious institutions will be able to leave their own significant imprint on the content of the right to freedom of religion and on the evergreen question regarding the relationship between religion and the state.

3. The Constitution creates this room for additional charters of rights because most rights guaranteed in the Constitution are described in cryptic, vague and general terms. The intention is that society, and specifically the state by way of legislation and other measures, and the courts through their judgments, must over time give further content to these rights. For example, the right to freedom of religion is protected in so many words in Section 15 of the Constitution, but Section 15 provides nothing else about the content of the right.

17. Both terms admit of a variety of interpretations. Whatever interpretations are given, however, extension of cooperation beyond simply one racial or religious group is implied and important.
4. In the case of several rights in the Constitution the state has already adopted separate acts of Parliament to further describe the content and application of the rights concerned. The following examples may be mentioned:

(a) Section 9 (the right to equality): the Promotion of Equality and Prevention of Unfair Discrimination Act, Act 4 of 2000

(b) Section 23 (labour rights): the Labour Relations Act, Act 66 of 1995

(c) Section 32 (the right to access to information): the Promotion of Access to Information Act, Act 2 of 2000

(d) Section 33 (the right to administrative justice): the Promotion of Administrative Justice Act, Act 3 of 2000

Directly or indirectly, numerous other acts give effect to the rights in the Constitution as well, as in the case of health, housing, education, the environment, the rights of children, the right to vote, and the rights of accused persons and prisoners. In addition, Section 234 creates yet another opportunity for such supplementary legislation.

5. There are a few reasons why a charter of religious rights may serve a useful purpose.

5.1. The right to freedom of religion as guaranteed in the Constitution is an important instrument regulating the relationship between religion and the state. As the supreme law of the Republic, the Constitution restricts in effect the powers of the state, because the state may not violate the rights in the Constitution without fulfilling the requirements of the Constitution. A charter of religious rights which further describes the content of the right, will outline even more clearly the relationship between religion and the state, and will secure the good relationship already existing between religion and the state. This relationship in terms of which freedom of religion and the autonomy of religious institutions are recognised, and religious institutions are accommodated positively and impartially in the state, should be stipulated unequivocally in a charter of religious rights.

5.2. By leaving the right to religious freedom undefined in the Constitution, one actually accepts that the content of the right will be determined through court decisions and other measures on an ad hoc basis, in other words, as issues and difficulties occur. This is a process over which religious institutions have little control. Section 234, on the contrary, creates the possibility to propose a charter of religious rights in which the content of the right is spelled out fully in a single charter.

5.3. Throughout history conflict between religion and the state occurred from time to time in most countries and there were even periods of large scale religious persecution. In our country, as well, issues sometimes occur over which religious institutions differ from the state or where the state take [sic] steps that limit or may limit religious freedom. By defining and stipulating clearly in an act this relationship, and what is allowed and what not, unnecessary state interference with religion which may occur in future can be prevented, and uncertainty, misunderstanding and unnecessary conflict between religion and the state can be eliminated.

5.4. A charter of religious rights can contribute to the spirit of tolerance prevailing between the various religions in South Africa. Compared to many other countries, South Africa is particularly blessed in this respect, and insofar 
as a charter of religious rights can enhance this spirit, South Africans should do their utmost to maintain and strengthen the good relationship among the different religions.

6. There are interesting international examples to which one may refer in this regard. All the primary international bills of rights protect the right to freedom of religion, but not a single one elaborates on the content of the right. (See for example Article 18 of the Universal Declaration of Human Rights, Article 18 of the International Convention on Civil and Political Rights, Article 9 of the European Convention for the Protection of Human Rights and Fundamental Freedoms, and Article 1 of the African Charter for Human and Peoples' Rights.) That is why the Declaration on the Elimination of All Forms of Intolerance and Discrimination Based on Religion or Belief, which spells out the content of the right to freedom of religion much more extensively, was adopted in 1981. (See also the Declaration on the Rights of Persons Belonging to National or Ethnic, Religious and Linguistic Minorities of 1992.) Domestically as well as internationally there are in other words precedents for a charter of religious rights.

We think this is a very important matter for the whole of South Africa and that we as religious communities have a big responsibility to make a contribution to freedom of religion in our country through a Charter of Religious Rights. We look forward to see you at the workshop.

Kind regards

(signed)

Pieter Coertzen, University of Stellenbosch (09 November 2007).

At the February 14, 2008 meeting, representatives of four religions, 33 Christian denominations and various individuals attended the workshop and worked through the proposed Charter to try and reach consensus. A few invited papers were delivered.

What occurred, and in spectacular fashion, was that the major religions present - Hindu, Christian (including Catholic, Orthodox, Zion Christian Church and Reformed branches), Jewish, Muslim and others gave one hundred percent support not only to the need for a document but to the process being used and the terms of the document itself.

A continuity committee was set up following the February 14, 2008 meeting made up of the following: Prof. P. Coertzen, theologian,Stellenbosch; Dr William Langeveldt, Commission of Culture, Religion and Linguistic Rights; Dr C. Landman - Commission for Culture, Religion and Linguistic Rights; Prof. Rassie Malherbe - Law, University of Johannesburg; Sheik Achmat Sedick - Muslim Judicial Counsel, Cape Town and; Rabbi Green - Jewish Orthodox Religion, Cape Town (representing Chief Rabbi Warren Goldstein, Chief Rabbi of South Africa). To this were added, in subsequent months: Iain T. Benson, lawyer and consultant, France and Canada; Dr. Nokosolo Ndende, University of South Africa, African Customary Religions and; Elder Eric Jackson, Church of Jesus Christ of Latter Day Saints, Johannesburg.

Meetings were held over the spring and summer of 2008 and included contact with the following groups in addition to those representatives from the major religions who had been at the Stellenbosch original meeting in February 2008: The House of Traditional Leaders, Pretoria (including all but two of their regional representatives); The Steering Committee for the Roman Catholic Bishops of South Africa (present was Cardinal Napier); The Central Committee of the Dutch Reformed Church; The South African Human Rights Commission; Editorial Committee for the Religion Hub (Television) of the South African Broadcasting Corporation; the Executive of the National Religious Leaders' Forum; The General Secretary of the South African Council of Churches; a representative of the South African Buddhist Religion and; a representative of the Rastafarian Religion.

\section{Conclusion of meetings}

The groups consulted (which eventually extended considerably beyond the above list) continued to express support and interest in the Charter. Many substantive comments were received, some of these from individuals and others from academics in many countries internationally. These consultations continued and at the time of the public signing of the draft in October 2010, version 6.0 represented the insights and contributions of hundreds of interventions, contributions and suggestions being made from throughout South Africa and internationally.

The process has allowed for very broad and deep consultation across a wide spectrum of religions in South Africa and some of the key groups involved in religion and human rights.

\section{The public signing ceremony and future anticipated steps}

The public signing of the document on October 21, 2010 at the main board room of the University of Johannesburg was followed by a meeting of the signatories that established a Council for Religious Rights and Freedoms pursuant to section 185 (1) (c) of the Constitution and other relevant provisions of the Promotion and Protection of Cultural, Religious and Linguistic Communities Act 19 of 2002. At the time of this writing a steering committee has been established of members and experts that will continue to raise support for the Charter and draft a Constitution for the Council to move ahead in discussions with the government. Those who have invested so much time and work in the process are hopeful that it will be passed into law for the guidance of South African society in future cases.

The document in its most recent version is attached as an Appendix to this article.

\section{Conclusion}

\section{The significance of the proposed Charter for South Africa and other countries}

What has occurred has been deep, meaningful and, might well be in the long run of great importance not only within 
South Africa but in many other countries as well. ${ }^{18}$ The process, document and meetings have shown both that religions can cooperate at a high level of sophisticated and mature discussion and that principles important to each religion can be shared and recognised as important to all religions. These principles are a substantive contribution to the principles of modus vivendi as they include not only the right to join a religion but also to leave one.

Finally, the process, which is ongoing, shows that there are alternatives to political and legal avoidance of key aspects when the civil society organisations themselves show leadership in important areas in the context of a constitutional document set up so as to encourage the involvement of civil society in its ongoing development. The process also provides a means of more holistic principled development than the ad hoc nature of litigation on a case-by-case basis.

In this respect, use of Section 234 of the South African Constitution provides an important landmark for those who are concerned that constitutional development has become the property of a small number of judges and activist litigation strategists.

It remains to be seen how the political process will respect the hard work that has been done by civil society. A sign of respect would be to recognise that the Charter represents an extraordinary cooperation between as wide a set of interest groups as could likely be assembled. It did not include every possible group - that goal would be impossible of realisation. It is for the Government, in conversation with the Council for Religious Rights and Freedoms that has been established, to determine whether Section 234 of the Constitution will prove to be useful and usable in South Africa.

\section{Acknowledgements}

The author would like to thank Prof. Shaun de Freitas who proofread the article, Hesma van Tonder for her expert librarian assistance and Pieter Coertzen and other members of the Continuity Committee for many years of rewarding work in relation to the Charter.

18.The author has met with officials at the Ministerial level provincially and federally in Canada to discuss whether, in principle, enactments could be developed that might serve in a manner akin to 'Interpretation Acts' in such a way that civil society initiatives could be both encouraged and effective in crafting greater delineation of the meaning of the general rights in the Canadian Charter of Rights and Freedoms. Should this occur it will be in no small part due to the South African experience in relation to that country's Section 234. In addition, discussions of the Charter and its processes have occurred in the United Kingdom, Italy and the United States and with delegates from some thirty-five other countries. In addition to the six African, English and Afrikaans versions of the Charter, it is available in German and plans are afoot to have it translated into Khoi/San, Italian, Spanish, French and Arabic. At the signing ceremony on October 21, 2010 portions of a letter in support of the process and its cultural importance from the Hon. Noel Kinsella, Speaker of the process and its cultural importance from the Hon. Noel Kinsella, Speaker of the international significance of the South African Charter.

\section{Competing interests}

The author declares that he has no financial or personal relationship(s) which may have inappropriately influenced him in writing this article. The author was co-counsel for the Interfaith Coalition for Marriage and the Family referred to in relation to the litigation regarding the definition of 'spouse' in the Egan and Nesbit case and counsel in the same-sex marriage cases in Canada referred to in the body of the text.

\section{References}

Benson, I.T., 2007, 'The freedom of conscience and religion in Canada: Challenges and opportunities', Emory International Law Review 21, 111-165.

Benson, I.T., 2008, 'The case for religious inclusivism and the judicial recognition of associational rights: a reply to Lenta', Constitutional Court Review 1, 297-312.

Benson, I.T. \& Miller, B., 2000, 'Equality and human dignity', Lex View 39, viewed 11 November 2012, from http://www.cardus.ca/lexview/article/2261/

Boonstra, K.L. \& Benson, I.T., 2006, 'The scope of protection for religious dissent regarding same-sex marriage', Lex View 54, viewed 11 November 2012, from http://www.cardus.ca/lexview/article/2324/

Boonstra, K.L. \& Benson, I.T. 2008, 'When should the courts enforce religious obligations?', Lex View 63, viewed 07 November 2010, from http://www.cardus. ca/lexview/article/2125/

Coertzen, P., 2007, 'Letter to Religious Groups and Leaders in South Africa', 09 November, Stellenbosch.

Currie, I. \& De Waal, J., 2005, Bill of Rights, 5th edn., Juta, Cape Town.

Egale, n.d., Equality for gays and lesbians everywhere, viewed 02 November 2012 from http://www.egale.ca

Farlam, P., 2003, 'Freedom of religion', in S. Woolman, T. Roux \& M. Bishop (eds.), Constitutional Law of South Africa, ch. 41, Juta, Kenwyn.

Hutchinson, A., 2005, 'Gay advocates fight churches' charity status', Ottawa Citizen, 12 June, viewed 05 November 2012, from http://www.virtueonline.org/portal/ modules/news/article. php? storyid=2609

Iacobucci, F., 2003, "'Reconciling rights" the supreme court of Canada's approach to competing charter rights', Supreme Court Law Review 20, 137-167.

Institute for the Study of Marriage, Law and Culture, n.d., viewed June 2013, from http://www.marriageinstitute.ca/homeeng.htm

Johansen, D. \& Rosen, P., 2008, 'The notwithstanding clause of the charter', in Parliament of Canada, viewed 19 September 2009, from http://www.parl.gc.ca/ Content/LOP/ResearchPublications/bp194-e.pdf

Lafferty, L.P., 2007, 'Religion, sexual orientation and the state: Can public officials refuse to perform same-sex marriages?', Canadian Bar Review 85, 287.

MacDougall, B., 2006, 'Refusing to officiate at same-sex civil marriages', Saskatchewan Law Review 69, 351-374.

Moon, R., 2008, 'Report to the Canadian Human Rights Commission concerning Section 13 of the Canadian Human Rights Act and the regulation of hate speech on the Internet', in Canadian Human Rights Commission, viewed 11 November 2012, from http://www.chrc-ccdp.ca/publications/report moon rapport/toc 2012, from

National Assembly (France), Parliamentary Commission, 2006, Report submitted on behalf of the mission of inquiry on the Family and the Rights of Children, viewed behalf of the mission of inquiry on the Family and the Rights of Children, viewed
18 September 2009, from http://www.preservemarriage.ca/docs/France_ Report_on_the_Family_Edited.pdf.

Robinson, B.A., 2002-2003, 'Homosexual (same-sex) marriages in Canada: Federal Parliamentary commission and discussion paper', in Religious Tolerance, viewed 20 April 2009, from http://www.religioustolerance.org/hom_marb5.htm

Sachs, A., 1990, Protecting human rights in a new South Africa: Contemporary South African debates, Oxford University Press, Cape Town.

Taylor, C., 1995, 'Liberal politics and the public sphere', in C. Taylor (ed.), Philosophical arguments, pp. 257-288, Harvard University Press, Cambridge. PMCid:1365000

Taylor, C., 2001, The malaise of modernity, Anansi Press, Canada. 


\section{Appendix 1}

\section{DRAFT South African Charter of Religious Rights and Freedoms (Version 6.0, August 2009) ${ }^{1}$}

General Outline: [Note: This Outline is for Convenience only and did not form part of the Charter as Signed]

1. Particularly notable amongst the provisions are the following:

2. Preamble, particularly \#7

3. Right to change religion 2.1

4. Principle of religious accommodation 2.2

5. Medical services or procedure protections 2.3

6. Non-establishment provision 3.1

7. Free-exercise provision 4.0 (including access to sacred places 4.1);

8. Freedom of expression (including public debate 6.1);

9. Right to share religious faith (6.1) including to attempt to convert others (6.2);

10. Access to public media (6.3) [a recent addition after representations from African customary religions about difficulty getting access to public media];

11. Advocacy of hatred "that constitutes incitement to immediate violence or physical harm" (6.4) [narrowing from "hate speech" which should be abolished from human rights according to Moon Report recently released in Canada $^{2}$;

12. Education, primary parental, right of information etc. (7.0)

13. Conditions of employment (9.1);

14. Relationship between Church and state recognising autonomy (9.3) and confessional protection (9.4);

15. Religion not defined by "service to adherents" so includes "whether they serve persons with different convictions". (12)

\section{South African Charter of Religious Rights and Freedoms (As amended 06 August 2009 and Signed October 21, 2010 - DRAFT Version 6.0)}

\section{Preamble}

1. WHEREAS human beings have inherent dignity, and a capacity and need to believe and organize their beliefs in accordance with their foundational documents, tenets of faith or traditions; and

2. WHEREAS this capacity and need determine their lives and are worthy of protection; and

3. WHEREAS religious belief embraces all of life, including the state, and the constitutional recognition and protection of the right to freedom of religion is an important mechanism for the equitable regulation of the relationship between the state and religious institutions; and

4. WHEREAS religious institutions are entitled to enjoy recognition, protection and co-operation in a constitutional state as institutions that function with jurisdictional independence; and

1.No earlier versions are given as a comparison of the changes made is beyond the scope of this article. Such an analysis, doubtless interesting, awaits future attention and would best follow final approval of the Charter and its passage into law.

2.This Report of Professor Richard Moon (2008) - dealing with hate speech laws and recommending their abolition in a Human Rights context - may be found at http:// www.chrc-ccdp.ca/publications/report_moon_rapport/toc_tdm-eng.aspx
5. WHEREAS it is recognized that rights impose the corresponding duty on everybody in society to respect the rights of others; and

6. WHEREAS the state through its governing institutions has the responsibility to govern justly, constructively and impartially in the interest of everybody in society; and

7. WHEREAS religious belief may deepen our understanding of justice, love, compassion, culture, democracy, human dignity, equality, freedom, rights and obligations, as well as our understanding of the importance of community and relationship in our lives and in society, and may therefore be beneficial for the common good; and

8. WHEREAS the recognition and effective protection of the rights of religious communities and institutions will contribute to a spirit of mutual respect and tolerance among the people of South Africa; and

\section{Therefore the following Charter of Religious Rights and Freedoms is hereby adopted as follows:}

1. Every person (where applicable in this Charter "person" includes a religious institution or association) has the right to believe according to their own religious or philosophical convictions, and to choose which faith, worldview, religion, or religious institution to subscribe to, affiliate with or belong to.

2. No person may be forced to believe, what to believe or not to believe, or to act against their convictions.

2.1.Every person has the right to change their faith, religion, convictions or religious institution, or to form a new religious community or religious institution.

2.2. Every person has the right to have their religious beliefs reasonably accommodated.

2.3. Every person may on the ground of their religious or other convictions refuse to (a) participate or indirectly assist in or refer for certain activities, such as of a military or educational nature, or (b) perform certain duties or deliver certain services, including medical or related (including pharmaceutical) services or procedures.

2.4. Every person has the right to have their religious or other convictions taken into account in receiving or withholding of medical treatment.

2.5. Every person has the right not to be subjected to any form of force or indoctrination that may cause the destruction of their religion, beliefs or worldview.

3. Every person has the right to the impartiality and protection of the state in respect of religion.

3.1. The state must create a positive and safe environment for the exercise of religious freedom, but may not as the state promote, favour or prejudice a particular faith, religion or conviction, and may not indoctrinate anyone in respect of religion.

3.2. No person may be unfairly discriminated against on the ground of their faith, religion, or religious affiliation.

4. Subject to the duty of reasonable accommodation and the need to provide essential services, every person has the right to the private or public, and individual or joint, 
observance or exercise of their religious beliefs, which may include but are not limited to reading and discussion of sacred texts, confession, proclamation, worship, prayer, witness, order, attire, appearance, diet, customs, rituals and pilgrimages, and the observance of religious and other sacred days of rest, festivals and ceremonies.

4.1. Every person has the right to private access to sacred places and burial sites relevant to their religious or other convictions. Such access, and the preservation of such places and sites, must be regulated within the law and with due regard for property rights.

4.2. Persons of the same conviction have the right to associate with one another, form, join and maintain religious and other associations, institutions and denominations, organise religious meetings and other collective activities, and establish and maintain places of religious practice, the sanctity of which shall be respected.

4.3. Every person has the right to communicate nationally and internationally with individuals and institutions on religious and other matters, and to travel, visit, meet and enter into relationships or association with them.

4.4. Every person has the right to single-faith religious observances, expression and activities in state or state-aided institutions, as regulated by the relevant institution, and as long as it is conducted on an equitable and free and voluntary basis.

5. Every person, religious community or religious institution has the right to maintain traditions and systems of religious personal, matrimonial and family law that are consistent with the Constitution and are recognised by law.

6. Every person has the right to freedom of expression in respect of religion.

6.1. Every person has the right to (a) make public statements and participate in public debate on religious grounds, (b) produce, publish and disseminate religious publications and other religious material, and (c) conduct scholarly research and related activities in accordance with their religious or other convictions.

6.2. Every person has the right to share their religious convictions with others on a voluntary basis.

6.3. Every religious institution has the right to have access to public media and public broadcasting in respect of religious matters and such access must be regulated fairly.

6.4. Every person has the right to religious dignity, which includes not to be victimised or slandered on the ground of their faith, religion, convictions or religious actions. The advocacy of hatred that is based on religion, and that constitutes incitement to imminent violence or to cause physical harm, is not allowed.

7. Every person has the right to be educated or to educate their children, or have them educated, in accordance with their religious or philosophical convictions.

7.1. The state, which includes any public school, has the duty to respect this right and to inform and consult with parents on these matters. Parents may withdraw their children from school activities or programs inconsistent with their religious or philosophical convictions.

7.2. Every educational institution may adopt a particular religious or other ethos, as long as it is observed in an equitable, free, voluntary and non-discriminatory way, and with due regard to the rights of minorities. The preference for a particular religious ethos does not constitute discrimination in breach of the constitution with respect to religious education.

7.3. Every private educational institution established on the basis of a particular religion, philosophy or faith may impart its religious or other convictions to all children enrolled in that institution, and may refuse to promote, teach or practice any religious or other conviction other than its own. Children (or their parents) who do not subscribe to the religious or other convictions practised in that institution waive their right to insist not to participate in the religious activities of the institution.

8. Every person has the right on a voluntary basis to receive and provide religious education, training and instruction. The state may subsidise such education, training and instruction.

9. Every religious institution has the right to institutional freedom of religion.

9.1.Every religious institution has the jurisdictional independence to (a) determine its own confessions, doctrines and ordinances, (b) decide for itself in all matters regarding its doctrines and ordinances, and (c) in compliance with the principles of tolerance, fairness and accountability regulate its own internal affairs, including organisational structures and procedures, the ordination, conditions of service, discipline and dismissal of office-bearers and members, the appointment, conditions of employment and dismissal of employees and volunteers, and membership requirements.

9.2. Every religious institution is recognised and protected as an institution that functions with jurisdictional independence, and towards which the state, through its governing institutions, has the responsibility to govern justly, constructively and impartially in the interest of everybody in society.

9.3. The state, including the judiciary, must respect the jurisdictional independence of every religious institution, and may not regulate or prescribe matters of doctrine and ordinances.

9.4. The confidentiality of the internal affairs and communications of a religious institution must be respected. Specifically, the privileged nature of any religious communication that has been made with an expectation of confidentiality must be respected in legal proceedings.

9.5.Every religious institution is subject to the law of the land, and must justify any disagreement, or civil dissent, on the basis of its religious convictions or doctrines. 
10. Every religious institution that qualifies as a juristic person has the right to participate in legal matters, for example by concluding contracts, acquiring, maintaining and disposal of property, and access to the courts. The state may allow religious institutions tax, charitable and other benefits.

11. Every person has the right, for religious purposes and in furthering their objectives, to solicit, receive, manage, allocate and spend voluntary financial and other forms of support and contributions. The confidentiality of such support and contributions must be respected.
12. Every person has the right on religious or other grounds, and in accordance with their ethos, and irrespective of whether they receive state-aid, and of whether they serve persons with different convictions, to conduct relief, upliftment, social justice, developmental, charity and welfare work in the community, establish, maintain and contribute to charity and welfare associations, and solicit, manage, distribute and spend funds for this purpose.

CContinuity Committee of the South African Charter of Religious Rights and Freedoms, (2010) and the Council for the Promotion of Religious Rights and Freedoms (2011). 